Scholedge International Journal of Management \& Development

ISSN 2394-3378, Vol.04, Issue 01 (2017)

Pg 1-9.

DOI: $10.19085 /$ journal.sijmd040101
Published by: Scholedge R\&D Center www.theSCHOLEDGE.org Email: editorial@thescholedge.org CPublisher

\title{
EVALUATION OF HUMAN-ENVIRONMENT INTERACTION IN RIVER OMINLA RIPARIAN CORRIDOR IN ORE TOWNSHIP, ONDO STATE, SOUTH WESTERN NIGERIA
}

\author{
Ayomide David Oluwatuyi \\ Institute of Ecology and Environmental Studies, Obafemi Awolowo University, Ile-Ife, Nigeria. \\ Aderemi Adediji \\ Department of Geography, Obafemi Awolowo University, Ile-Ife, Nigeria. \\ Ajayi Adeola \\ Department of Public Administration, Obafemi Awolowo University, Ile-Ife, Nigeria.
}

\begin{abstract}
The study was aim to assess the condition resulted from riparian encroachment in the study area with a view to provide a baseline information for urban and surface water sustainable development. Primary and secondary data were employed. Primary data involved field survey using questionnaire in which 245 copies were administered to the selected riparian residents to evaluate their perception and experience on human effects on riparian vegetation, water body and resultant problems. Secondary data involved an existing relevant data. The data were analysed using descriptive statistics. The survey results showed that urban growth had resulted to loss of farmland/garden (73.9\%), riparian natural forest (86.1\%), medicinal tree/herbs and shrub (77.1\%), and useful timbers (62.8\%). Riparian deforestation had also resulted to high sedimentation of the river basin (77.6\%), increased river seasonal volume (76.7\%),enhanced access of solid particles/materials into the river (76.7\%), loss of riparian animals (82.9\%), pollution of the river (75.5\%) riparian flooding (75.9\%) that subsequently resulted to loss of lives and properties (84.1\%) and loss of valuable plant (95.9\%).Therefore, the study concluded that there is significant negative effects of anthropogenic activities on River Ominla Riparian corridor and that this requires urgent attention.
\end{abstract}

KEYWORDS: Anthropogenic, riparian corridor, urban growth, ecotone. 


\section{Introduction}

Riparian zones are transition zones between an upland terrestrial environment and aquatic environment (Molles, 2008). According to Richardson (2007), importance of riparian zones include preventing erosion, protecting water quality, providing and wildlife corridors and maintenance of in-stream biota. Nevertheless, authors have pointed out that riparian ecosystem for ages has been under anthropogenic threats. Many riparian degradations resulted from anthropogenic activities involved hydrologic modification and habitat alteration (Meritts et al., 2000). Stromberg (1993) opined, diverting water from stream channels for agricultural, industrial and human use reduces volume of water in ecotone. Dams can cause substantial changes in downstream riparian communities by altering the magnitude, frequency and timing of flood events (Meritts and Cooper, 2000). Hawkins and Kershner (1997) discovered that many places around the world riparian zone have been completely eliminated as humans have cleared land for raising crops, growing timbers, and developing land for commercial or residential purposes. Michelib (2004), removing of riparian vegetation increases the credibility of the stream banks, and also speed the rate of channel migration. Another effect on riparian ecosystem is yet identified by Stromberg (1993), mining of sand and gravel can directly destroy habitat, alter stream channel morphology and change sediment flow. According to Oriola (2012), flow accumulation spots, coupled with refuse dumps were identified as key factors that heighten the level of flood susceptibility. Urbanization, deforestation, desertification, over population and all kinds of pollution are some of the resultant effects of man's interaction with his environment (Omofonmwan et al., 2008). Pollution from wastes brought by increased runoff caused environmental or visual blight (Adebayo, 2014). The world's rain forests could completely vanish in a hundred years at the current rate of deforestation (National Geographic, 2016). This has direct implication on water, aquatic and terrestrial condition. According to Eni et'al., (2011), approximately fifty percent of urban growth influenced water quality. Currently, concerns are being raised regionally and globally about the health of the basin with regard to pollution, overexploitation of its resources and technological developments affecting biodiversity and the overall function as a watershed (Charles et al., 2011). These concerns have led to increased emphasis on environmental risks assessment studies all over the world (Olorukoba, 2009).

In the light of foregoing, few studies earlier carried out in this field (area of study)and other related areas in Nigeria covered the study area. It is therefore pertinent to assess current anthropogenic trend of the study area to aid sustainable planning and development using hence this study.

\section{Study objectives}

This paper aims at assessing the condition resulted from interaction of the riparian residence with specific objectives to:

i. Enumerate the closest house units to the water body within and along the riparian corridor; 
ii. Evaluate perception/experience of riparian residents on effects of urban growth on vegetation, water body and associated hazards.

\section{Study Area}

The study area is in Ore Township in Odigbo Local Government Area, Ondo State, Southwestern Nigerian (see fig 1.). It lies between Lat. $6^{\circ} 42^{\prime}$ and $6^{\circ} 56^{\prime}$ North and Long. $4^{\circ} 49^{\prime}$ and $4^{\circ} 56^{\prime}$ East. River Ominla and its riparian ecosystem traverse the township in the East from the North to the South. Its form a trellarse drainage with different hydro-edgesfrom several locations in the landscape.

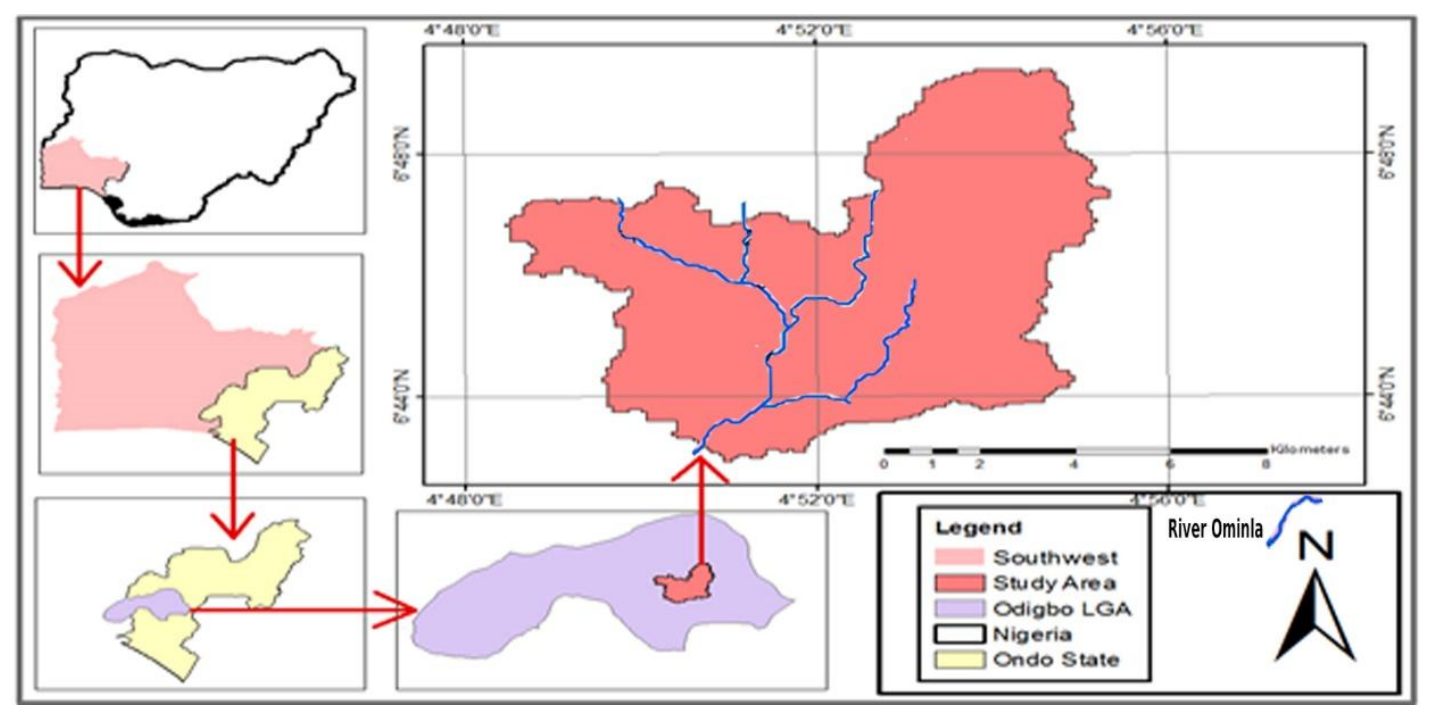

Figure 1: The Study Area

One of its major tributaries is River Irore that flows from the northeast of the basin.

\section{Study Methodology}

Primary data was sourced from field survey involving direct field observation, enumeration and questionnaire administration. In order to validate the data, questionnaires were administered to the riparian residence along and closest to the water body. The house units enumerated within this boundary were 620 . A respondent in each of the house units constituted the study population. But the sample size was 245(ie.39.5\%) using Slovin Formula (Slovin and Altares, 2003) (at margin error 5\% and 95\% confidence level). The housing units closest to the water body within the ecotone were systematically sampled while respondent in each was purposively selected for interview. In order to choose the sample size of 245 , the total housing units were divided into sample frames 400, 200, and 20 respectively. In sample frame 400, 200 were sampled at interval of 2 (i.e. 1-in-2). In sample frame 200, 40 were sampled at interval of 5 (i.e.1in-5). Also in sample frame 20, 5 housing units were sampled at interval of 4 (i.e. 1-in-4). Simultaneously, a respondent in each sampled housing unit was purposively selected based on certain conditions such as 
year of residency (each of at least 5 years) and age (above 18 years). In all, a total of 245 respondents were sampled/selected for the study. Descriptive statistical technique was used to analyse the responses using Excel Spreadsheet.

\section{Results and Discussion}

It is pertinent to generate the demographic and socio-economic characteristics of the respondents in the riparian environment. This was put in Section A (Respondent bio data) of the questionnaire. This section surveyed the age range, sex, year of residency, highest education, and occupation or respondent. The survey revealed $30.6 \%$ majority of the respondents were on age range 18-29 years. This was followed by $29.4,23.7,9.4$, and $6.9 \%$ at range 30-39,50-59, 40-49, and above 60 years respectively. In gender diversity survey, largest percent (51.8\%) of the respondents were male while female were $48.2 \%$. In evaluating year of residency of the respondents, survey showed that 136 (55.5\%) majority had been residing close to the river in the year range of 6-10 years. This could give a background idea that reliable responses is obtainable. Also, it was recorded that $25.3 \%, 12.2 \%, 5.7 \%$ and $1.2 \%$ had range 11-15, 16-20, above 20 and 5 years respectively. The highest education level attainment of respondents was also unfolded as majority of $54.3 \%$ were secondary education next by $23.7 \%$ and $22.0 \%$ of tertiary and non formal education respectively. Majority $40.8 \%$ of the respondents were into trading as their occupation. This was next by others at $24.9 \%$ i.e. other occupation beside those defined in the survey. Also, $18 \%$ were artisan, $9.8 \%$ civil servant and $6.5 \%$ farming respectively.

Section 1,2, and 3 was generally designed to carry out survey on perception of people on anthropogenic effects on the riparian corridor. Section 1 surveyed effects on vegetation. Section 2 surveyed effects on River Ominla condition while Section 3 evaluated hazards/problems resulted from riparian deforestation and River Ominla condition (see Table 1, 2 and 3). 
Table 1: Responses on anthropogenic effects on riparian vegetation

\begin{tabular}{|c|c|c|c|c|c|c|c|c|c|c|c|}
\hline S/no & Question & SD & $\mathrm{D}$ & $\mathrm{T}$ & $\%$ & NI & $\%$ & A & SA & $\mathrm{T}$ & $\%$ \\
\hline 1 & $\begin{array}{l}\text { Urban growth has resulted to loss of } \\
\text { farmland/garden }\end{array}$ & 13 & 50 & 63 & 25.7 & 1 & 0.4 & 74 & 107 & 181 & 73.9 \\
\hline 2 & $\begin{array}{l}\text { Urban growth has resulted to loss of air } \\
\text { cooling riparian natural forest }\end{array}$ & 13 & 21 & 34 & 13.9 & 0 & 0 & 95 & 116 & 211 & 86.1 \\
\hline 3 & $\begin{array}{l}\text { Urban growth has resulted to loss of } \\
\text { riparian medicinal tree, herbs and shrub }\end{array}$ & 3 & 51 & 54 & 22.0 & 1 & 0.4 & 53 & 136 & 189 & 77.1 \\
\hline 4 & $\begin{array}{l}\text { Urban growth has resulted to loss of forest } \\
\text { reserve }\end{array}$ & 108 & 34 & 142 & 58 & 1 & 0.4 & 32 & 70 & 102 & 41.7 \\
\hline 5 & $\begin{array}{l}\text { Urban growth has resulted to loss of useful } \\
\text { timbers }\end{array}$ & 58 & 33 & 91 & 37.2 & 0 & 0 & 76 & 78 & 154 & 62.8 \\
\hline
\end{tabular}

Note: SA is Strongly Agree; D is Disagree; T is Total; A is Agree; NI is No Idea and SA is Strongly Agree

The survey in Table 1 shows the relationship between urban growth and riparian vegetation. It has been discovered that urban growth has resulted to loss of farmland/garden as $73.9 \%$ agreed, $25.7 \%$ disagreed, while $0.4 \%$ had no idea about the change. Thus, many unbuilt plot of land mainly for farms and gardens have been replaced by buildings. Majority of the respondents, $86.1 \%$ has agreed that urban growth has resulted to loss of air cooling riparian natural forest, $13.9 \%$ disagreed while $0 \%$ had no idea. Many trees that were formally serving this function have been replaced by building. Many were removed for construction and firewood. Approximately seventy seven (77.1\%) agreed to the fact that urban growth had resulted to loss of riparian medicinal tree, herbs and shrubs, $22.0 \%$ disagreed while $0.4 \%$ has no idea. Majority of the respondents, $58 \%$ has concluded that urban growth has not resulted to loss of forest reserve, $41.7 \%$ agreed while $0.4 \%$ had no idea. This is connected to the fact that the reserve was under protection of government. Forest guards were always on patrol to ensure its prevention from encroachment. The larger percentage of $62.8 \%$ of respondents has concluded that urban growth has resulted to loss of useful timbers, $37.2 \%$ disagreed as $0 \%$ had no idea. Many useful timbers outside forest reserve have been used for construction and firewood purposes.

These results were in line with Hawkins and Kershner, (1997)'s finding. They discovered that many places around the world riparian zone have been completely eliminated as humans have cleared, and developed land for commercial or residential purposes. 
Table 2: Responses on anthropogenic effects on River Ominla

\begin{tabular}{|c|c|c|c|c|c|c|c|c|c|c|c|}
\hline S/no & Question & SD & D & $\mathrm{T}$ & $\%$ & NI & $\%$ & A & SA & $\mathrm{T}$ & $\%$ \\
\hline 1 & $\begin{array}{l}\text { Riparian deforestation has } \\
\text { contributed to high sediment in } \\
\text { the River Ominla river basin }\end{array}$ & 45 & 10 & 55 & 22.5 & 0 & 0 & 84 & 106 & 190 & 77.6 \\
\hline 2 & $\begin{array}{l}\text { Riparian deforestation has } \\
\text { contributed to increase in the } \\
\text { river seasonal volume }\end{array}$ & 6 & 50 & 56 & 22.8 & 1 & 0.4 & 110 & 78 & 188 & 76.7 \\
\hline 3 & $\begin{array}{l}\text { Riparian deforestation has } \\
\text { contributed to decrease in the } \\
\text { river seasonal volume }\end{array}$ & 68 & 104 & 172 & 70.2 & 2 & 0.8 & 12 & 59 & 71 & 28.9 \\
\hline 4 & $\begin{array}{l}\text { Riparian deforestation has } \\
\text { aided access of solid } \\
\text { particles/materials into the } \\
\text { river and change its colour }\end{array}$ & 22 & 34 & 56 & 22.9 & 1 & 0.4 & 46 & 142 & 188 & 76.7 \\
\hline 5 & $\begin{array}{l}\text { Riparian deforestation has } \\
\text { contributed to loss of edible } \\
\text { riparian aquatics like crab, } \\
\text { snail, periwinkle etc. }\end{array}$ & 8 & 16 & 24 & 9.8 & 18 & 7.3 & 70 & 133 & 203 & 82.9 \\
\hline
\end{tabular}

Note: SA is Strongly Agree; D is Disagree; T is Total; A is Agree; NI is No Idea and SA is Strongly Agree

The associated consequence or effect of riparian deforestation or urban growth on River Ominla condition was surveyed and analysed. Majority of the respondents, $77.6 \%$ concluded that riparian deforestation has contributed to high sediment in the River Ominla basin, $22.5 \%$ disagreed. This was associated with the remover of vegetation that formally protected or held the soil together against erosion. Since rain could fall on the soil directly, displace, and transport it by the action of runoff and finally deposit it in the river channel. Based on the analysis of the responses, it was revealed that riparian deforestation has resulted to seasonal increase in the volume of the river as $76.7 \%$ respondents agreed, $22.8 \%$ disagree and $0.4 \%$ had no idea on this. This can be linked to poor percolation, infiltration or seepage of runoff resulted from remover of vegetation that used to provide pores through root system for absorbing the surface runoff and 
raindrops. Besides, larger part of the community had been concretized or exposed. This easily aided increase in runoff that find its way to the river channel. This further supported opinion of Micheli (2004), that removing of riparian vegetation increases the credibility of the stream banks, and also speed the rate of channel migration. The larger percentage of respondents of $76.8 \%$ agreed that riparian deforestation has aided access of solid particles/materials into the river and thus change its colour, while $22.9 \%$ disagree as $0.4 \%$ had no idea. It is natural function of riparian vegetation to filter runoff water before getting to river. The absence of the vegetation thus aided their access. This is in agreement with respondent's conclusion in Table 3 that riparian deforestation has aided pollution of the river. Riparian deforestation has contributed to loss of edible riparian aquatics like crab, snail, periwinkle etc., from the responses analysed, $82.9 \%$ agreed, $9.87 .3 \%$ disagree while $7.3 \%$ had no idea about the question/issue under consideration i.e. the loss of edible riparian aquatics.

Table 3: Problem resulting from riparian deforestation and River Ominla condition

\begin{tabular}{|c|c|c|c|c|c|c|c|c|c|c|c|}
\hline S/no & Question & SD & $\mathrm{D}$ & $\mathrm{T}$ & $\%$ & NI & $\%$ & A & SA & $\mathrm{T}$ & $\%$ \\
\hline 1 & $\begin{array}{l}\text { Riparian deforestation has } \\
\text { aided River Ominla pollution }\end{array}$ & 44 & 6 & 50 & 20.4 & 10 & 4.1 & 102 & 83 & 185 & 75.5 \\
\hline 2 & $\begin{array}{l}\text { River Ominla is currently } \\
\text { good for domestic purposes } \\
\text { like cooking, drinking, } \\
\text { washing etc. }\end{array}$ & 91 & 74 & 165 & 67.1 & 0 & 0 & 64 & 16 & 80 & 32.7 \\
\hline 3 & $\begin{array}{l}\text { Riparian deforestation has } \\
\text { contributed to riparian } \\
\text { flooding }\end{array}$ & 9 & 0 & 9 & 3.7 & 1 & 0.4 & 71 & 164 & 235 & 75.9 \\
\hline 4 & $\begin{array}{l}\text { Lives or properties are being } \\
\text { loss to flooding in the } \\
\text { riparian environment. }\end{array}$ & 24 & 15 & 39 & 15.9 & 0 & 0 & 63 & 143 & 206 & 84.1 \\
\hline 5 & $\begin{array}{l}\text { Riparian deforestation has } \\
\text { led to loss of valuable plant } \\
\text { and animal }\end{array}$ & 1 & 8 & 9 & 3.7 & 0 & 0 & 77 & 159 & 236 & 95.9 \\
\hline
\end{tabular}

Note: SA is Strongly Agree; D is Disagree; T is Total; A is Agree; NI is No Idea and SA is Strongly Agree 
This section surveyed the hazard/problems resulted from human interaction or action through riparian deforestation and River Ominla condition. The majority of the respondents, 75.5\% agreed that riparian deforestation has aided River Ominla pollution, 20.4\% disagreed while $4.1 \%$ had no idea. Removal of vegetation aided surface runoff to easily transport waste from community into the river since there was no filter mechanism. Consequently, survey revealed that River Ominla is currently not good for domestic purposes like cooking and drinking as $67.1 \%$ respondents agreed against $32.6 \%$ disagree respondents who disagreed, while $0 \%$ had no idea. This is a pointer to unsustainable culture of some of riparian residents who found it easier and cost effective to dump their wastes. The survey further revealed that riparian deforestation has contributed to riparian flooding as $95.9 \%$ majority of respondents agreed, $3.7 \%$ disagreed, $0.4 \%$ had no idea. This can be easily traced to an unsustainable interaction with the river. Many house units seemed too close to the channel while there were no physical evidence that some of them were built under urban and regional planning regulation. The majority of respondents, $84.1 \%$ agreed that lives/properties are being lost to flooding in riparian environment, $15.9 \%$ disagreed. One of the causes could be some of the house units were too close to the river. Evidently, another causes including incessant dumping of waste that obstructed free flow and accumulation of sediment in the river channel. The survey further indicated that riparian deforestation has resulted to biodiversity loss of valuable plants and animal with $95.9 \%$ of respondents agreeing to this while $3.7 \%$ disagreed.

The findings supported Meritts et al., (2000) with opinion that many riparian degradation resulted from anthropogenic activities involved hydrologic modification and habitat alteration and yet reminded of Charles et al., (2011)s' concerns. They earlier pointed out, concerns are being raised regionally and globally about the health of the basin with regard to pollution, overexploitation of its resources and technological developments affecting biodiversity and the overall function as a watershed.

\section{Conclusion}

Assessment of anthropogenic effects on River Ominla ecotone has been successfully carried out to discover current human-environment relation dynamic in the region. Ever-increasing built-up has resulted to loss of natural vegetation in River Ominla riparian corridor in Ore Township. Subsequently, deforestation and other anthropogenic activities in the area had posed unending threat on the available surface water. This chain of unsustainable development had resulted to series of environmental hazards and problems. Though urban growth and expansion is unavoidable, but unsustainable development is avoidable to the barest minimum.

As part of the effect in achieving Sustainable Development Goals (SDGs) 11 and encourage eco-friendly society in developing nations, results and recommendation of the study worth meticulous attention. This study has drawn attention of all to act on behalf of the degrading and dying nature and gave recommendations. There is an urgent need for riparian reforestation/restoration. Base on the knowledge of rate of deforestation in the region, various vegetation species could be re-introduced to replace 
proportionately as possible the lost ones. There is also the need for proper town planning. Town planner should adopt modern technique instead of bare-footed approach to evaluate, plan, and manage anthropogenic activities in the area. A standard and exclusive house unit setback (buffer) to the River Ominla and tributaries should be created. However, town planning laws should be adequately enforced and implemented. The research further recommended provision of environmental awareness scheme for the riparian dwellers. There is need for them to understand their environment and the consequences of unsustainable development as well as sustainable culture. The concerned health workers and stakeholders should make further investigation into the pollution report to avert pending epidemic war in the riparian environment.

\section{Reference}

1. Adebayo, W.O, (2014). Environmental Effects of Urbanization of River Ajilosun Drainage Basin in Ado-Ekiti, Ekiti State, Nigeria.

2. Eni, D. I.,Obiefuna, J. N., Oko, C. and Innocent, (2011). Impact of Urbanization On Sub Surface Water Quality in Calabar Municipality, Nigeria Department of Geography and Regional Planning University of Calabar, Calabar, Nigeria. International Journal of Humanities and Social Science. 1(10): 167.

3. Godwin, C.N.; Harkins, C.P; Kershner, J.L.(1997). Riparian restoration in the western United States: Overview and perspective. Restoration Ecology 5(4SUPPL): - 14.

4. Hawkins, C. P., K.L. Bartz, and C. M. U. Neale. 1997. Vulnerabil- ity of riparian vegetation $t$ catastrophic flooding: implications for riparian restoration. Restoration Ecology 54S:75-84.

5. Meritts, D.J; Cooper, D.M. (2000). Riparian vegetation and channel changein response toriver regulation: A comparative study of regulated and unregulated streams in the Green River Basin, USA. Regulated River Research and Management 16(6): 543-564.

6. Michelib, E.R, Kirchner, J.W; Larsen, E.W.(2004). Quantifying the effect of riparian forest versus agricultural vegetation on river meander migration rates, Central Sacramento River, Califonia, USA. River and Application 20(5): 53-58

7. Molles, M.C. Jr. (2008). Ecology oncepts and Applications ( $4^{\text {th }}$ ed.). New York: McGraw-Hill p.291.

8. Omofonmwan,S. I. and Osa-Edoh,G. I. (2008). The Challenges of Environmental Problems in Nigeria. Geography and Planning and 2 Educational Foundation, Ambrose Ali University Ekpoma, Nigeria.

9. Omofonmwan, S. I., and G. I. Osa-Edoh (2015). "The Challenges of Environmental Problems in Nigeria." Journal of Human Ecology 23.1 (2008): 53-57.

10. Oriola, E. and Sadiat. B. (2012). Urban Flood Risk Information on a River Catchment in a Part of Ilorin Metropolis, Kwara State. Nigeria Information and Knowledge Management. 2(8): 70

11. Richardson. D.M, et al (2007). Riparian vegetation: degradation, alien plant invasions and restoration prospects. Diversity and Distributions 13(1):126-139

12. Stromberg, J.C (1993). Freemont Cottonwood Goodding Willow Riparian Forests: A review of Their Ecology, Threat and Recovery Potentials.Jounal of Arizonal Nevada Academy of Science 27: 9-110

13. Swanson, F.J, S.V Gregory, J.R. Sedell, and A.G. Cambell., (1982). Land-water interactions: The riparian zone In Analysis of Coniferous Forest Ecosystem in the Western United State. Edited by R.L. Edwards, 26-291. 